\title{
Effect of soil application of humic acid and bio-humic on yield and fruit quality of "Kalamata" olive trees
}

\author{
E. Abd El-Razek* (1), Laila F. Haggag(D, Eman S. El-Hady® and M. F. M. Shahin』
}

\begin{abstract}
Background: The present study was carried out during the two successive seasons of 2016 and 2017 on "Kalamata" olive trees (Olea europaea L.), at a private orchard located on Cairo-Ismailia Km 107 desert Road, Egypt. The trees were treated with four soil applications as follows: (T1) control (water only), (T2) organic matter of $10 \mathrm{~kg}$ chicken manure was added in both side of the tree under drip irrigation system at the $1^{\text {st }}$ week of January, (T3) organic matter $+100 \mathrm{~cm}^{3}$ humic acid (Actosol') for each tree, (T4) organic matter + bio-humic which contain $100 \mathrm{~cm}^{3}$ Actosol and $150 \mathrm{~cm}^{3}$ of Azotobacter chroococcum, Bacillus megaterium, and Bacillus circulans in equal doses. Humic acid and bio-humic were added 3 times at the $1^{\text {st }}$ week of March (full bloom), at $1^{\text {st }}$ week of May (starting fruit set stage), and at the last week of July in the third stage of fruit development (70\% of final fruit size) to study the effect of humic acid and bio-humic on the yield and fruit quality of Kalamata olive trees.

Results: The result showed that all treatments improve the nutrient status ( $N, P, K, C a, M g, F e, Z n, M n, C u$ ) of the leaves, yield (kg/tree) and fruit quality, i.e., fruit weight, volume, specific gravity, dimension, and shape index, as well as fruit moisture content percentage and oil percentage in FW and DW than the control. Within all treatments, the bio-humic treatment (T4) is recommended, since it had the highest value of these parameters in comparison with the other treatments or control.

Conclusion: It could be concluded that improving yield and fruit quality attributed to the positive effect of organic matter alone or in combination with humic or bio-humic in increasing the cation exchange capacity of the soil, reducing soil pH, enhancing the root development, increasing the root/shoot ratio, and production of root hairs of olive trees which increase the active uptake for most of the nutrients in the soil. In addition, bio-humic contains three bacteria that are now considered as plant growth-promoting rhizobacteria (PGPR) that play a great role in providing trees with NPK as bio-fertilizers and increased also the mineral status. Therefore, bio-humic positive effects reflected on improving the yield and fruit quality of Kalamata olive trees. In general, organic manure in combination with bio-humic had great effects on improving the yield and fruit quality of Kalamata olive trees than using organic manure alone or use organic manure combined with humic acid.
\end{abstract}

Keywords: Olive, Humic acid, Bio-humic, Azotobacter chroococcum, Bacillus megaterium, Bacillus circulans, Yield, Fruit quality

\footnotetext{
*Correspondence: emad71_9@yahoo.com

Pomology Department, Agricultural and Biological Division, National

Research Centre (NRC), 33 Elbehouth St., Dokki, Giza 12622, Egypt
}

\section{Springer Open}

(c) The Author(s). 2020 Open Access This article is licensed under a Creative Commons Attribution 4.0 International License, which permits use, sharing, adaptation, distribution and reproduction in any medium or format, as long as you give appropriate credit to the original author(s) and the source, provide a link to the Creative Commons licence, and indicate if changes were made. The images or other third party material in this article are included in the article's Creative Commons licence, unless indicated otherwise in a credit line to the material. If material is not included in the article's Creative Commons licence and your intended use is not permitted by statutory regulation or exceeds the permitted use, you will need to obtain permission directly from the copyright holder. To view a copy of this licence, visit http://creativecommons.org/licenses/by/4.0/. 


\section{Background}

Olive cultivation (Olea europaea L.) has been widespread in many countries throughout the world since several hundred years due to that it is an important fruit crop for human nutrition and many food industries such as oil extracting, pickling, and fodder. All ancient civilizations of the Mediterranean basin and parts of Asia Minor (Egyptians, Phoenicians, Greeks, and Romans) contributed to the spread of olive cultivation in this region. Today, the olive oil industry occupied a huge economic sector in many countries due to that olive oil has many health benefits such as it is a non-saturated oil and has a fine aroma and pleasant taste, and due to these advantages, its production is approximately 3,144 , 000 tons of oil/year according to IOOC; however, Egypt produces 27,500 tons of olive oil/year (IOOC, 2019a). In Egypt, the cultivation area is approximately 73,774 ha $(177,058$ Feddan; 1 ha $=2.4$ Fed. $)$ which produces about 768,176 tons (FAO, 2018). Egypt is considered one of the top producers of table olives in the world and produces about 690,000 tons which presented $23.6 \%$ of the world's table olives production (IOOC, 2019b). "Kalamata" olive cultivar is considered one of the most important commercial table olive varieties in Egypt and needs special treatments under sandy soil and other types of reclaimed soils condition, since the poor soil fertility and low water holding capacity are generally the main soil problems that influence on Kalamata yield and fruit quality.

However, many factors affected the olive tree productivity such as the nutrition statue and the environmental conditions like poor soil fertility and low water holding capacity which are generally the principal soil problems. Under these soil problems, organic matters, humate substances, and bio-fertilizers avoid these soil problems and reduce the costs of fertilization. In this regard, humic acid and bio-humic (humic acid combined with symbiotic bacteria) are bio-stimulants that enhance trees' growth and they help to withstand harsh environments when applied in small quantities (Chen et al., 1994). Moreover, various functions were noticed when they are applied such as the positive influence on enhancing the root development, increasing the root/shoot ratio, and production of thin lateral roots of olive plants as a result to its component of heterogeneous mixture of several composite behaviors (Tattini et al., 1991). In addition, humic acid and bio-humic are composed of leonardite coal, and this organic matter stimulates both root and vegetative growth as a result to raise cation exchange capacity that activates nutrient uptake, beneficial microorganism in the soil, tolerance to different stress (drought and heat), and difficult environment conditions such as low organic matter and unavailability of soil nutrients (Russo and Berlyn, 1990, Tattini et al., 1990,
Chunhua et al., 1998, Eissa et al., 2007, Ismail et al., 2007 and Haggag Laila et al., 2015a, b). Furthermore, both of humic acid and bio-humic improve the nutrient availability and nutrient uptake due to its mode of action that is similar to chelating agent performance which facilitates the availability of nutrients and also its mode of action like auxins that enhance root growth (O'Donnell, 1973, Tatini, et al., 1990 and Khattab et al., 2012).

Bio-fertilizers applied instead of the chemical fertilizers is considered a favorite target to achieve sustainability in olive production. In this respect, Azotobacter chroococcum strains used as the nitrogen biofertilizer due to that it plays a principal role in adapting the atmospheric nitrogen through its fixation in the roots. Azotobacter chroococcum can improve the soil fertility, since the aerobic bacteria that belong to the genus Azotobacter represent a diverse group of free-living diazotrophic (with the ability to use $\mathrm{N}_{2}$ as the sole nitrogen source) and these microorganisms commonly occur in the soil. The genus Azotobacter includes 6 species and Azotobacter chroococcum is the most common inhabiting in various soils over all the world (Mahato et al., 2009). In addition, Bacillus megaterium and Bacillus circulans are phosphate $(\mathrm{P})$ - and potassium (K)-solubilizing bacteria, respectively, and they are used as biofertilizers due to that they may enhance mineral uptake by plants through solubilizing insoluble $\mathrm{P}$ and releasing $\mathrm{K}$ from silicate in the soil (Goldstein and Liu, 1987). A group of bacteria is now considered as plant growth-promoting rhizobacteria (PGPR), which participate in many key ecosystem processes such as those involved in the biological control of plant pathogens, nutrient cycling, and seedling establishment and therefore deserve particular attention for agricultural or forestry purposes (Elo et al., 2000). PGPR may colonize the rhizosphere, the surface of the root, or even superficial intercellular spaces of plants (McCully, 2001).

The aim of this research is to study the effect of organic manure in combination with humic acid or in combination with bio-humic (which consist of humic acid combined with three plant growth-promoting rhizobacteria (PGPR); Azotobacter chroococcum is used as nitrogen biofertilizer, Bacillus megaterium and Bacillus circulans which are used as phosphate $(\mathrm{P})$ - and potassium (K)-solubilizing bacteria) on the yield and fruit quality of Kalamata olive trees.

\section{Materials and methods}

\section{Plant materials}

The present study was carried out during the two successive seasons of 2016 and 2017 on Kalamata olive trees (Olea europaea L.) at a private orchard located on Cairo-Ismailia Km 107 desert Road, Ismailia Governorate, Egypt. Table 1 showed the analyses of orchard well 
Table 1 Analysis of the orchard well water

\begin{tabular}{ll}
\hline $\mathrm{pH}$ & 7.49 \\
$\mathrm{EC}\left(\mathrm{dSm}^{-1}\right)$ & 4.40 \\
Soluble cations (meq/l) & \\
$\mathrm{Ca}^{++}$ & 7.50 \\
$\mathrm{Mg}^{++}$ & 5.00 \\
$\mathrm{Na}^{+}$ & 33.10 \\
$\mathrm{~K}^{+}$ & 0.16 \\
$\mathrm{Soluble}^{+}$anions (meq/l) & \\
$\mathrm{CO}_{3}{ }^{-}$ & - \\
$\mathrm{HCO}_{3}{ }^{-}$ & 1.60 \\
$\mathrm{Cl}^{-}$ & 40.00 \\
$\mathrm{SO}_{4}{ }^{-}$ & 4.16 \\
\hline
\end{tabular}

water and Table 2 presented the analysis of the physical and chemical properties of the orchard soil. The experimental trees were about 15 years old, spaced at $5 \times 6 \mathrm{~m}$ within deferent varieties, cultivated in sandy soil under a drip irrigation system, similar in growth vigor, and received the same horticultural practices.

The following treatments were applied:

$\mathrm{T} 1=$ Control (water only)

$\mathrm{T} 2$ = Organic matter $(10 \mathrm{~kg}$ chicken manure was added in both sides of the tree under a drip irrigation system) at the $1^{\text {st }}$ week of January

$\mathrm{T} 3=$ Organic matter $+100 \mathrm{~cm}^{3}$ humic acid (Actosol $\left.{ }^{\circ}\right)$ for each tree

$\mathrm{T} 4$ = Organic matter + bio-humic (mixed of $100 \mathrm{~cm}^{3}$ Actosol and $150 \mathrm{~cm}^{3}$ of Azotobacter chroococcum, $B$. megaterium, and $B$. circulans in equal doses.

Table 2 Analysis of physical and chemical properties of the orchard soil

\begin{tabular}{|c|c|c|c|}
\hline \multirow[t]{2}{*}{ Parameters } & \multicolumn{3}{|c|}{ Depth parameters of simple $(\mathrm{cm})$} \\
\hline & Superficial sample & $30 \mathrm{~cm}$ & $60 \mathrm{~cm}$ \\
\hline $\mathrm{pH}(2.5: 1)$ & 8.7 & 8.02 & 8.11 \\
\hline$E C\left(d S m^{-1}\right)(1: 1)$ & 0.8 & 3.85 & 1.75 \\
\hline \multicolumn{4}{|c|}{ Soluble cations (meq/l) } \\
\hline $\mathrm{Ca}^{++}$ & 6.05 & 2.55 & 3.05 \\
\hline $\mathrm{Mg}^{++}$ & 4.05 & 1.55 & 1.55 \\
\hline $\mathrm{Na}^{+}$ & 28.60 & 4.45 & 12.95 \\
\hline $\mathrm{K}^{+}$ & 0.12 & 0.14 & 0.78 \\
\hline \multicolumn{4}{|c|}{ Soluble anions (meq/l) } \\
\hline $\mathrm{CO}_{3}=$ & - & - & - \\
\hline $\mathrm{HCO}_{3}^{-}$ & 4.45 & 2.45 & 2.05 \\
\hline $\mathrm{Cl}^{-}$ & 27.25 & 5.05 & 13.05 \\
\hline $\mathrm{SO}_{4}=$ & 7.12 & 1.14 & 3.18 \\
\hline
\end{tabular}

where humic acid and bio-humic were added 3 times at $1^{\text {st }}$ week of March (full bloom), at $1^{\text {st }}$ week of May (starting fruit set stage), and at the last week of July in the third stage of fruit development ( $70 \%$ of final fruit size).

\section{Bio-humic preparation}

Bio-humic consisted of humic acid plus liquid cultures of three bacteria: Azotobacter chroococcum, Bacillus megaterium, and Bacillus circulans. They are provided by the Unit of Biofertilizers, Faculty of Agriculture, Ain Shams University. Each organism was grown separately in batch culture to the late exponential phase of each microorganism to give a cell suspension of $5 \times 10^{5}, 6 \times$ $10^{7}$, and $4 \times 10^{7}$ cell $/ \mathrm{ml}$ for Azotobacter chroococcum, B.megaterium, and B. circulans, respectively. Cultures were mixed on site in equal doses to form 1 liter of biofertilizer. Then, each 1 liter of biofertilizer was mixed with 1 liter of humic acid .

\section{Yield and fruit quality}

The yield was harvested at $1^{\text {st }}$ November and recorded as kilograms/tree. Fifty fruits were handpicked randomly from all sides of each tree at harvest (100\% purple flesh and dark purple skin) to determine the following fruit quality: fruit weight $(\mathrm{g})$, fruit volume $\left(\mathrm{cm}^{3}\right)$, fruit length and diameter $(\mathrm{cm})$, shape index $(\mathrm{L} / \mathrm{D})$, fruit moisture content (\%), and fruit oil content in dry and fresh weight (\%) according to AOAC (1990).

\section{Leaf mineral content}

Macro-nutrients were determined in dry leaf samples which are collected from each tree at the harvest on $1^{\text {st }}$ November in both seasons. N\% was measured by MicroKjeldahl according to Pregel (1945). Also, P\% was determined as described by Champman and Parker (1961), while $\mathrm{K} \%$ was measured according to Brown and Lilleland (1945). Mg, Ca, Fe, $\mathrm{Zn}, \mathrm{Mn}$, and $\mathrm{Cu}$ were determined by the atomic adsorption spectroscopy (AAS) method according to A.O.A.C (1990).

\section{Statistical analysis}

Data were analyzed by analysis of variance (ANOVA), and means were compared using Duncan's test at $p<$ 0.05 to determine the significance of differences between the conducted treatments (Duncan, 1955).

\section{Results}

Table 3 illustrated the effect of soil application with humic acid or bio-humic (humic acid combined with three bacteria: Azotobacter chroococcum, Bacillus megaterium, and Bacillus circulans) on total yield, fruit weight, and volume, as well as fruit specific gravity of Kalamata olive trees. It is clear that $\mathrm{T} 4$ recorded the 
Table 3 Effect of soil application of humic acid and bio-humic on yield, fruit weight, and volume, as well as fruit specific gravity of Kalamata olive trees

\begin{tabular}{|c|c|c|c|c|c|c|c|c|}
\hline \multirow[t]{2}{*}{ Treatments } & \multicolumn{2}{|c|}{ Yield (kg/tree) } & \multicolumn{2}{|c|}{ Fruit weight (g) } & \multicolumn{2}{|c|}{ Fruit volume $\left(\mathrm{cm}^{3}\right)$} & \multicolumn{2}{|c|}{ Fruit specific gravity $\left(\mathrm{g} / \mathrm{cm}^{3}\right)$} \\
\hline & $\begin{array}{l}1^{\text {st }} \\
\text { season }\end{array}$ & $\overline{2^{\text {nd }}}$ season & $\begin{array}{l}1^{\text {st }} \\
\text { season }\end{array}$ & $\overline{2^{\text {nd }}}$ season & $\begin{array}{l}1^{\text {st }} \\
\text { season }\end{array}$ & $\overline{2^{\text {nd }}}$ season & $\begin{array}{l}1^{\text {st }} \\
\text { season }\end{array}$ & $2^{\text {nd }}$ season \\
\hline $\mathrm{T} 1=$ Control & $43.33 d$ & $48.31 \mathrm{~d}$ & $5.15 d$ & $5.44 \mathrm{~d}$ & $5.28 d$ & $5.71 \mathrm{~d}$ & $0.975 \mathrm{~b}$ & $0.953 \mathrm{~b}$ \\
\hline $\mathrm{T} 2=$ Organic matter & $70.67 \mathrm{c}$ & $60.27 c$ & $5.66 c$ & $6.16 c$ & $5.63 c$ & $6.08 c$ & $1.005 \mathrm{a}$ & $1.014 \mathrm{a}$ \\
\hline $\mathrm{T} 3$ = Organic matter + humic acid & $81.00 \mathrm{~b}$ & $75.43 \mathrm{~b}$ & $6.22 \mathrm{~b}$ & $7.23 \mathrm{~b}$ & $6.17 b$ & $7.03 \mathrm{~b}$ & $1.008 \mathrm{a}$ & 1.029 a \\
\hline $\mathrm{T} 4$ = Organic matter + bio-humic & $89.67 \mathrm{a}$ & $83.65 \mathrm{a}$ & $6.52 \mathrm{a}$ & $7.74 a$ & $6.46 a$ & $7.50 \mathrm{a}$ & $1.010 \mathrm{a}$ & $1.032 \mathrm{a}$ \\
\hline
\end{tabular}

Means within a column followed by different letter(s) are statistically different at $5 \%$ level

highest value in these parameters. Concerning the yield, all treatments improved the yield than the control (T1). $\mathrm{T} 4$ gave the highest yield/tree in both seasons (89.67 and $83.65 \mathrm{~kg} /$ tree) followed by T3 (81.00 and $75.43 \mathrm{~kg} /$ tree). In addition, $\mathrm{T} 2$ came in the third order and achieved 70.67 and $60.27 \mathrm{~kg} /$ tree in both years, whereas the control (T1) recorded the lowest yield in both seasons (43.33 and $48.31 \mathrm{~kg} /$ tree). Regarding the fruit weight, all treatments produced higher weight than the control. T4 achieved the heaviest weights in both seasons (6.52 and $7.74 \mathrm{~g}$ ) followed by T3 which had 6.22 and $7.23 \mathrm{~g}$ in the two studied years. T2 came also in third place (5.66 and $6.16 \mathrm{~g}$ ), while the T1 (control) had the lowest fruit weight during this study (5.15 and $5.44 \mathrm{~g}$ ). The same trend was found in the fruit volume as affected by treatments. Concerning the fruit specific gravity, it is clear that all treatments improve this parameter (arranged from 1.005 to $1.010 \mathrm{~g} / \mathrm{cm}^{3}$ in the $1^{\text {st }}$ season and from 1.014 to $1.032 \mathrm{~g} / \mathrm{cm}^{3}$ in the $2^{\text {nd }}$ season than the control ( 0.975 and $0.953 \mathrm{~g} / \mathrm{cm}^{3}$, respectively).

The results in Table 4 showed the effect of soil application of humic acid and bio-humic on fruit dimensions and shape index of Kalamata olive trees. Data revealed that all treatments affected the fruit dimension more than the control (T1) in both years. In this regard, T4 had the highest length and width in both seasons $(L=$ 2.96 and $2.98 \mathrm{~cm}, W=2.08$ and $2.26 \mathrm{~cm}$ ), followed by T3 $(L=2.71$ and $2.77 \mathrm{~cm}, W=1.96$ and $2.18 \mathrm{~cm})$, while T2 came in the third class $(L=2.58$ and $2.51 \mathrm{~cm}, W=$ 1.89 and $1.95 \mathrm{~cm})$. The control was the last order $(L=$ 2.08 and $2.02 \mathrm{~cm}, W=1.52$ and $1.56 \mathrm{~cm})$. Concerning the shape index, T4 was different among all treatments including the control and achieved L/D = 1.42 and 1.32 in both seasons.

Table 5 presented the effect of soil application of humic acid and bio-humic on moisture content percentage and oil content percentage in dry and fresh weights of Kalamata olive trees. It is clear from the result that all treatments had higher values in these parameters than the control (T1). The highest value of moisture content percentage was achieved by T4 (58.04 and 56.17\%) in both seasons, followed by $\mathrm{T} 2$ and $\mathrm{T} 3$ which had the same significant value and recorded 47.77 and $49.79 \%$ in the $1^{\text {st }}$ year and 48.36 and 49.98 in the $2^{\text {nd }}$ year, respectively, while the control recorded the lowest moisture content percentage in the two years (34.26 and $36.31 \%)$. Oil percentage in dry weight (DW) increased by all treatments than the control (T1). In this regard, the quality of Kalamata olive as pickling variety improved as a result to increase the oil content percentage in dry and fresh weights. T4 had the highest oil percentage in DW (45.00 and $43.07 \%$ in both years), followed by T3 (41.03 and $40.33 \%$ ), whereas there was no significant difference between T4 and T3. Moreover, T2 came in the second order (39.65 and $38.80 \%$ in both seasons) and was nonsignificant with T3. The lowest oil percentage in DW was noticed by the control (35.10 and 36.20\%). The same trend was found in oil percentage in fresh weight (FW), since T4 produced the highest value in both seasons (31.56 and 32.11\%), followed by T3 which had 26.08 and $25.77 \%$, then T2 which had 22.26 and $22.10 \%$, while the control had the smallest value (16.36 and 18.90\%).

Table 4 Effect of soil application of humic acid and bio-humic on fruit dimensions and shape index of Kalamata olive trees

\begin{tabular}{|c|c|c|c|c|c|c|}
\hline \multirow[t]{2}{*}{ Treatments } & \multicolumn{2}{|c|}{ Fruit length $(\mathrm{cm})$} & \multicolumn{2}{|c|}{ Fruit width (cm) } & \multicolumn{2}{|c|}{ Shape index (L/D) } \\
\hline & $1^{\text {st }}$ season & $2^{\text {nd }}$ season & $1^{\text {st }}$ season & $2^{\text {nd }}$ season & $1^{\text {st }}$ season & $2^{\text {nd }}$ season \\
\hline $\mathrm{T} 1=$ Control & $2.08 \mathrm{C}$ & $2.02 \mathrm{C}$ & $1.52 \mathrm{C}$ & $1.56 \mathrm{C}$ & $1.36 \mathrm{~b}$ & $1.29 \mathrm{~b}$ \\
\hline $\mathrm{T} 2=$ Organic matter & $2.58 \mathrm{~b}$ & $2.51 \mathrm{~b}$ & $1.89 \mathrm{~b}$ & $1.95 \mathrm{~b}$ & $1.37 \mathrm{~b}$ & $1.29 \mathrm{~b}$ \\
\hline $\mathrm{T} 3=\mathrm{T} 2+$ humic acid & $2.71 \mathrm{ab}$ & $2.77 \mathrm{ab}$ & $1.96 \mathrm{ab}$ & $2.18 \mathrm{ab}$ & $1.38 \mathrm{ab}$ & $1.27 b$ \\
\hline $\mathrm{T} 4=\mathrm{T} 2+$ bio-humic & $2.96 \mathrm{a}$ & $2.98 \mathrm{a}$ & $2.08 \mathrm{a}$ & $2.26 \mathrm{a}$ & $1.42 \mathrm{a}$ & $1.32 \mathrm{a}$ \\
\hline
\end{tabular}

Means within a column followed by different letter(s) are statistically different at $5 \%$ level 
Table 5 Effect of soil application of humic acid and bio-humic on moisture content \% and oil content \% in dry and fresh weights of 'Kalamata' olive trees

\begin{tabular}{|c|c|c|c|c|c|c|}
\hline \multirow[t]{2}{*}{ Treatments } & \multicolumn{2}{|c|}{ Moisture content (\%) } & \multicolumn{2}{|c|}{ Oil in dry weight (\%) } & \multicolumn{2}{|c|}{ Oil in fresh weight (\%) } \\
\hline & $1^{\text {st }}$ season & $2^{\text {nd }}$ season & $1^{\text {st }}$ season & $2^{\text {nd }}$ season & $1^{\text {st }}$ season & $2^{\text {nd }}$ season \\
\hline $\mathrm{T} 1=$ Control & $34.26 c$ & $36.31 \mathrm{c}$ & $35.10 \mathrm{c}$ & $36.20 c$ & $16.36 \mathrm{C}$ & $18.90 \mathrm{c}$ \\
\hline $\mathrm{T} 2$ = Organic matter & $47.77 \mathrm{~b}$ & $48.36 \mathrm{~b}$ & $39.65 b$ & $38.80 \mathrm{~b}$ & $22.26 b$ & $22.10 \mathrm{~b}$ \\
\hline $\mathrm{T} 3=\mathrm{T} 2+$ humic acid & $49.79 \mathrm{~b}$ & $49.98 \mathrm{~b}$ & $41.03 \mathrm{ab}$ & $40.33 a b$ & $26.08 \mathrm{ab}$ & $25.77 \mathrm{ab}$ \\
\hline $\mathrm{T} 4=\mathrm{T} 2+$ bio-humic & $58.04 \mathrm{a}$ & $56.17 \mathrm{a}$ & $45.00 \mathrm{a}$ & $43.07 \mathrm{a}$ & $31.56 \mathrm{a}$ & $32.11 \mathrm{a}$ \\
\hline
\end{tabular}

Means within a column followed by different letter(s) are statistically different at $5 \%$ level

Therefore, T4 was the best treatment that increased the oil percentage in DW and FW among all treatments.

Table 6 cleared the effect of soil application of humic acid and bio-humic on $\mathrm{N}, \mathrm{P}, \mathrm{K}, \mathrm{Ca}$, and $\mathrm{Mg}$ leaf mineral content of Kalamata olive trees. Concerning NPK, T4 had the highest content of NPK among all treatments during the two seasons $(\mathrm{N}=1.92$ and $1.98 \%, \mathrm{P}=0.19$ and $0.21 \%$, and as $\mathrm{K}=1.35$ and $1.38 \%$ ). In addition, $\mathrm{T} 3$ was the second order in NPK content $(\mathrm{N}=1.46$ and $1.54 \%, \mathrm{P}=0.17$ and $0.19 \%$, and $\mathrm{K}=1.23$ and $1.24 \%$ ). Moreover, T2 recorded the third grade in NPK content $(\mathrm{N}=1.10$ and $1.24 \%, \mathrm{P}=0.13$ and $0.15 \%$, and $\mathrm{K}=1.14$ and $1.16 \%$ ), while the control (T1) recorded the lowest content of NPK among all treatments through the two seasons of this study $(\mathrm{N}=0.97$ and $1.00 \%, \mathrm{P}=0.10$ and $0.11 \%$, and $\mathrm{K}=0.99$ and $0.96 \%$ ). Regarding $\mathrm{Ca}$ and $\mathrm{Mg}$ leaf content, all treatments increased the leaf content of these elements than the control. T4 was the highest content in $\mathrm{Ca}$ and $\mathrm{Mg}$ leaf content in the two years $(\mathrm{Ca}=$ 1.19 and $1.20 \%, \mathrm{Mg}=0.17$ and $0.16 \%$ ), followed by $\mathrm{T} 3$ $(\mathrm{Ca}=0.98$ and $0.96 \%, \mathrm{Mg}=0.13$ and $0.14 \%)$, and then came T2 $(\mathrm{Ca}=0.78$ and $0.77 \%, \mathrm{Mg}=0.10$ and $0.11 \%)$, whereas the control (T1) had the lowest $\mathrm{Ca}$ and $\mathrm{Mg}$ leaf content in the two years $(\mathrm{Ca}=0.63$ and $0.65 \%, \mathrm{Mg}=$ 0.08 and $0.09 \%)$. T4 was the superior treatment between all treatments including the control in $\mathrm{N}, \mathrm{P}, \mathrm{K}, \mathrm{Ca}$, and Mg leaf content.

Table 7 showed the effect of soil application of humic acid and bio-humic on leaf microelement content of Kalamata olive trees. $\mathrm{Fe}, \mathrm{Mn}, \mathrm{Zn}$, and $\mathrm{Cu}$ leaf content were increased by all treatments than the control. In this respect, $\mathrm{T} 4$ was the promising treatment among all treatments, since it had the highest value of $\mathrm{Fe}, \mathrm{Mn}, \mathrm{Zn}$, and $\mathrm{Cu}$ leaf content $\left(61,41,35\right.$, and $7.56 \mathrm{ppm}$ in the $1^{\text {st }}$ year, respectively, and $65,42,37$, and 7.64 in the $2^{\text {nd }}$ year, respectively), followed by T3 $(55,36,30$, and 6.51 ppm in the $1^{\text {st }}$ year, respectively, and $57,35,32$, and 6.73 in the $2^{\text {nd }}$ year, respectively) and $\mathrm{T} 2(51,33,23$, and $6.00 \mathrm{ppm}$ in the $1^{\text {st }}$ year, respectively, and $50,30,24$, and 6.05 in the $2^{\text {nd }}$ year, respectively), whereas the control (T1) gave the lowest value of leaf content $(30,23,16$, and $4.50 \mathrm{ppm}$ in the $1^{\text {st }}$ year, respectively, and $32,21,18$, and 4.38 in the $2^{\text {nd }}$ year, respectively).

\section{Discussion}

Olive trees' growth, total yield, and fruit quality are affected by many environmental factors and nutritional status. In this regard, poor fertility of soil as well as low water holding capacity in general present the major soil troubles which impact on the yield and fruit quality. Therefore, the trees need organic fertilizers to improve the soil characteristics and to reduce the costs of fertilization as well as to avoid soil pollution which caused by chemical fertilization. In this research, besides adding the organic manure, humic and bio-humic not only play a great function in raising the water holding capacity by increasing cation exchange capacity but also improve the nutritional status as a result to activate nutrient uptake and beneficial microorganism due to the positive effect of humic acid and bio-humic in enhancing the root development, increasing the root/shoot ratio, and production of thin lateral roots of olive plants which enhance the active uptake for most of the nutrients in

Table 6 Effect of soil application of humic acid and bio-humic on N, P, K, Ca, and Mg leaf mineral content of Kalamata olive trees

\begin{tabular}{|c|c|c|c|c|c|c|c|c|c|c|}
\hline \multirow[t]{2}{*}{ Treatments } & \multicolumn{2}{|l|}{ N (\%) } & \multicolumn{2}{|l|}{$\mathrm{P}(\%)$} & \multicolumn{2}{|l|}{ K (\%) } & \multicolumn{2}{|l|}{$\mathrm{Ca}(\%)$} & \multicolumn{2}{|l|}{ Mg (\%) } \\
\hline & $1^{\text {st }}$ season & $2^{\text {nd }}$ season & $1^{\text {st }}$ season & $2^{\text {nd }}$ season & $1^{\text {st }}$ season & $2^{\text {nd }}$ season & $1^{\text {st }}$ season & $2^{\text {nd }}$ season & $1^{\text {st }}$ season & $2^{\text {nd }}$ season \\
\hline $\mathrm{T} 1=$ Control & $0.97 d$ & $1.00 \mathrm{~d}$ & $0.10 \mathrm{~d}$ & $0.11 \mathrm{~d}$ & $0.99 \mathrm{~d}$ & $0.96 \mathrm{~d}$ & $0.63 d$ & $0.65 d$ & $0.08 \mathrm{~d}$ & $0.09 \mathrm{~d}$ \\
\hline $\mathrm{T} 2$ = Organic matter & $1.10 \mathrm{c}$ & $1.24 \mathrm{C}$ & $0.13 c$ & $0.15 c$ & $1.14 \mathrm{c}$ & $1.16 \mathrm{c}$ & $0.78 c$ & $0.77 c$ & $0.10 \mathrm{c}$ & $0.11 c$ \\
\hline $\mathrm{T} 3=\mathrm{T} 2+$ humic acid & $1.46 \mathrm{~b}$ & $1.54 \mathrm{~b}$ & $0.17 b$ & $0.19 b$ & $1.23 \mathrm{~b}$ & $1.24 \mathrm{~b}$ & $0.98 \mathrm{~b}$ & $0.96 \mathrm{~b}$ & $0.13 \mathrm{~b}$ & $0.14 b$ \\
\hline $\mathrm{T} 4=\mathrm{T} 2+$ bio-humic & $1.92 \mathrm{a}$ & $1.98 \mathrm{a}$ & $0.19 \mathrm{a}$ & $0.21 \mathrm{a}$ & $1.35 \mathrm{a}$ & $1.38 \mathrm{a}$ & $1.19 \mathrm{a}$ & $1.20 \mathrm{a}$ & $0.17 \mathrm{a}$ & $0.16 \mathrm{a}$ \\
\hline
\end{tabular}

Means within a column followed by different letter(s) are statistically different at $5 \%$ level 
Table 7 Effect of soil application of humic acid and bio-humic on leaf microelements content of Kalamata olive trees

\begin{tabular}{|c|c|c|c|c|c|c|c|c|}
\hline \multirow[t]{2}{*}{ Treatments } & \multicolumn{2}{|l|}{ Fe (ppm) } & \multicolumn{2}{|l|}{$\mathrm{Mn}$ (ppm) } & \multicolumn{2}{|l|}{ Zn (ppm) } & \multicolumn{2}{|l|}{$\mathrm{Cu}(\mathrm{ppm})$} \\
\hline & $1^{\text {st }}$ season & $2^{\text {nd }}$ season & $1^{\text {st }}$ season & $2^{\text {nd }}$ season & $1^{\text {st }}$ season & $2^{\text {nd }}$ season & $1^{\text {st }}$ season & $2^{\text {nd }}$ season \\
\hline $\mathrm{T} 1=$ Control & $30 c$ & $32 c$ & $23 c$ & $21 \mathrm{c}$ & $16 \mathrm{~d}$ & $18 d$ & $4.50 \mathrm{c}$ & $4.38 \mathrm{c}$ \\
\hline $\mathrm{T} 2$ = Organic matter & $51 \mathrm{~b}$ & $50 \mathrm{~b}$ & $33 \mathrm{~b}$ & $30 \mathrm{~b}$ & $23 c$ & $24 c$ & $6.00 \mathrm{~b}$ & $6.05 b$ \\
\hline $\mathrm{T} 3=\mathrm{T} 2+$ humic acid & $55 \mathrm{ab}$ & $57 \mathrm{ab}$ & $36 \mathrm{ab}$ & $35 \mathrm{ab}$ & $30 \mathrm{~b}$ & $32 \mathrm{~b}$ & $6.51 \mathrm{ab}$ & $6.73 a b$ \\
\hline $\mathrm{T} 4$ = $\mathrm{T} 2+$ bio-humic & $61 \mathrm{a}$ & $65 \mathrm{a}$ & $41 \mathrm{a}$ & $42 \mathrm{a}$ & $35 a$ & $37 a$ & $7.56 \mathrm{a}$ & $7.64 \mathrm{a}$ \\
\hline
\end{tabular}

Means within a column followed by different letter(s) are statistically different at $5 \%$ level

the soil. This fact was confirmed by Tattini et al. (1991) and their findings explain our results.

Bio-humic was more characterized than the humic acid with the included 3 beneficial bacteria: Azotobacter chroococcum which utilizes the atmospheric nitrogen through its fixation in the roots as well as Bacillus megaterium and Bacillus circulans that release phosphate (P) and potassium $(\mathrm{K})$ from the soil to a simple form which will be able to uptake by roots. This true parallel with Weller and Thomashow (1993), Glick (1995), Elo et al. (2000), and McCully (2001) who reported that a group of bacteria are now considered as plant growthpromoting rhizobacteria (PGPR), which participate in nutrient cycling. PGPR may colonize the rhizosphere, the surface of the root, or even superficial intercellular spaces of the plants. Therefore, these findings could clarify why the bio-humic treatment (T4) achieved higher yield and fruit quality than using organic manure alone or combined with humic acid which also improves theses parameters.

It is clear that organic matter combined with humic acid or bio-humic improves the leaf content of the macro-element $\mathrm{N}, \mathrm{P}, \mathrm{K}, \mathrm{Ca}$, and $\mathrm{Mg}$ as well as the micro-element $\mathrm{Fe}, \mathrm{Zn}, \mathrm{Mn}$, and $\mathrm{Cu}$, and this attribute to the effect of organic matter, humic or bio-humic, on improving nutrient uptake due to the increase in the cation exchange. Bio-humic gave higher mineral leaf content in compression with humic acid treatment as a result it contains three PGPR: Azotobacter chroococcum used as nitrogen biofertilizer and Bacillus megaterium and Bacillus circulans which are used as phosphate (P)- and potassium (K)-solubilizing bacteria that provided the trees with the mineral nutrient and raised the mineral leaf content. These findings were in harmony with Russo and Berlyn (1990), Tattini et al. (1990), Chunhua et al. (1998), Eissa et al. (2007), Ismail et al. (2007), and Haggag Laila et al. (2015a, b).

Also, the improving nutrient availability can attribute to the role of humic acid and bio-humic in enhancing the nutrient uptake in the form of a chelating agent as well as that both of them may enhance root growth in a similar mode of action to auxins. This explanation is in agreement with O'Donnell (1973), Tatini et al. (1990), Tao et al. (2008), and Khattab et al. (2012).

In a general, the result proved that organic manure compound with humic acid or bio-humic had a positive influence on increasing leaf mineral status that reflected on improving yield and fruit quality, especially the treatment of bio-humic (T4) which maximized the yield and gave excellent fruit quality due to the bio-humic content of the mentioned three PGPR that play a great role in providing trees with NPK as bio-fertilizers and increased the mineral status. This is in agreement with many researchers that found the same effect on increasing seedling growth, growth vigor, and yield and fruit quality of fruit trees as a result to improve the mineral status, and they confirmed our results. This concerns with Senn and Kingman (2000), Rengrudkij and Partida (2003), Mohammed et al. (2010), Abd El-Razek et al. (2012), Khattab et al. (2012), Khattab et al. (2014), Abobatta (2015), Abdel-Hayani and Hadi (2015), Haggag Laila et al. (2015a, b), Sándor et al. (2015), Ennab (2016), Jahromi and Khankahdani, (2016), Abd El-Rheem et al. (2017), Asgharzade and Babaeian (2012), Ferrara and Brunetti (2008), Haggag Laila et al. (2013), Rahil and Jabi (2015), Shahin et al. (2015), Mosa et al. (2016), Abd El-Rhman (2017), Danyaei et al. (2017), Hidayatullah et al. (2018) and Abd El-Razek et al., (2018a, b).

\section{Conclusion}

The application of organic manure alone or combined with humic or bio-humic had positive effects on improving the total yield and fruit quality of Kalamata olive trees. However, soil application of organic manure (10 $\mathrm{kg}$ chicken manure was added in both sides of the tree under drip irrigation system) at the $1^{\text {st }}$ week of January combined with bio-humic (mixed of $100 \mathrm{~cm}^{3}$ Actosol and $150 \mathrm{~cm}^{3}$ of Azotobacter chroococcum, B. megaterium, and B. circulans in equal doses) added 3 times at the $1^{\text {st }}$ week of March (full bloom), at the $1^{\text {st }}$ week of May (starting fruit set stage), and at the last week of July in the third stage of fruit development (70\% of final fruit size) is recommended to improve the nutrient status $(\mathrm{N}$, $\mathrm{P}, \mathrm{K}, \mathrm{Ca}, \mathrm{Mg}, \mathrm{Fe}, \mathrm{Zn}, \mathrm{Mn}, \mathrm{Cu})$ and the total yield $(\mathrm{kg} /$ 
tree) and fruit quality (fruit weight, volume, specific gravity, dimension, and shape index, as well as fruit moisture content percentage and oil percentage in FW and DW) of Kalamata olive trees. In this respect, improving the mineral status and productivity (yield and fruit quality) attributed to the positive effect of organic matter, humic and bio-humic, in improving the cation exchange capacity of the soil, reducing soil $\mathrm{pH}$, enhancing the root development, increasing the root/shoot ratio, and production of thin lateral roots of olive plants. In addition, bio-humic contains three bacteria that are now considered as plant growth-promoting rhizobacteria (PGPR) that play a great role in providing trees with NPK as bio-fertilizers that increased also the mineral status. All of these effects increase the active uptake for most of the nutrients in the soil. Therefore, the organic manure in combination with bio-humic had positive effects reflected on improving the yield and fruit quality of Kalamata olive trees than using organic manure alone or combined with humic acid.

\section{Abbreviations}

PGPR: Plant growth-promoting rhizobacteria; FAO: Food and Agriculture Organization of the United Nation; IOOC: International Olive Oil Council; CA: California; USA: United State of America; AOAC: The Association of Official Analytical Chemists

\section{Acknowledgements}

Not applicable

\section{Authors' contributions}

This work was carried out in collaboration between all authors. Author LFH designed the study, wrote the protocol, managed the field works, and reviewed the final draft of the manuscript; Author EA managed the literature searches, participated in the field application, collected the field samples for physical and chemical analyses, tabled the field data for the statistical analyses, prepared the samples for analyses, and wrote the first draft of the manuscript. Author ESE conducted the field applications, tabled the field data for the statistical analyses, prepared the samples for analyses, conducted the physical and chemical analyses, and performed the statistical analyses. Author MFMSh participated in the field works, collected field samples, and tabled the data for statistical analyses. The authors read and approved the final manuscript.

\section{Funding}

Not applicable

\section{Availability of data and materials}

The datasets generated and/or analyzed during the current study are included in this published study.

\section{Ethics approval and consent to participate}

Not applicable

\section{Consent for publication}

Not applicable

\section{Competing interests}

The authors declare that they have no competing interests.
Received: 13 February 2020 Accepted: 14 April 2020

Published online: 15 May 2020

\section{References}

Abd El-Razek E, Abd-Allah ASE, Saleh MMS (2012) Yield and fruit quality of Florida prince peach trees as affected by foliar and soil applications of humic acid. J Appl Sci Res 8(12):5724-5729

Abd El-Razek E, Haggag Laila F, Abd-El-Migeed MMM, El-Hady Eman S (2018 a) Combined effects of soil applications of humic acid and foliar spray of amino acids on yield and fruit quality of 'Florida Prince' peach trees under calcareous soil conditions. Bioscience Research, 15(4):3270-3282. Available at: https://www.isisn.org/BR15(4)2018/3270-3282-15(4)2018BR18-172.pdf.

Abd El-Razek E, Haggag Laila F, Genaidy EAE, El-Hady Eman S (2018 b) Influence of soil application of bio-regulators with Greenpower, pigeon manure tea and humic acid on yield and fruit quality of 'Aassy' olive trees (Olea europaea L.). Bioscience Research, 15(4):3459-3471.

Abd El-Rheem Kh M, Mohammed KAS, El-Damarawy YA (2017) Effect of humic and fulvic acid on growth, yield and nutrients balance of "Costata" persimmon trees. J Agric Food Tech 7(4):1-5

Abd El-Rhman IE (2017) Effect of magnetic iron and potassium humate on growth, yield and fruit quality of pomegranate trees in Siwa Oasis. Egypt Inter J Enviro 6(3):103-113

Abdel-Hayani AM, Hadi Basma S (2015) Effect of foliar application of humiic acid and seaweed extract on fruit characteristics and yield of grapevine Halawani cultivar. Egy J Appl Sci 30(10):670-681

Abobatta WF (2015) Influence of magnetic iron and K-humate on productivity of Valencia orange trees (Citrus Sinensis L.) under salinity conditions. Inter J Scientific Res Agri Sci 2:108-119

AOAC (1990) Official Methods of Analysis. The Association of Official Analytical Chemists. 15th Ed. Arlington, West Virginia, Washington D.C., USA.

Asgharzade A, Babaeian M (2012) Investigating the effects of humic acid and acetic acid foliar application on yield and leaves nutrient content of grape (Vitis vinifera). African J Microbiol Res 6(31):6049-6054

Brown JD, Lilleland FH (1945) Rapid determination of potassium and sodium in plant material and soil extracted by flam photometer. Proc Amer Soc Hort Sci 48:341-346

Chapman HD, Parker F (1961) Methods of analysis for soil, plant and water. California Univ., public division of agricultural sciences. Berkeley, CA, USA.

Chen, Y, Magen H, Riov J (1994) Humic substances originating from rapidly decomposing organic matter. Proc. Int. Meet. $6^{\text {th }}$ Sep. 1992: 427- 443, (Chem. Abst. 121:229).

Chunhua L, Cooper RJ, Bowman DC (1998) Humic acid application affects photosynthesis, root development and nutrient content of creeping bentagrass. Hort Sci 33(6):1023-1025

Danyaei A, Hassanpour S, Baghaee MA, Dabbagh M, Babarabie M (2017) The effect of sulfur-containing humic acid on yield and nutrient uptake in olive fruit. Open J Eco 7:279-288

Duncan DBC (1955) Multiple range and multiple F tests. Biometrics 11:1-42

Eissa Fawzia M, Faith MA, El-Shall SA (2007) The role of humic acid and rootstock in enhancing salt tolerance of "Le-Conte" pear seedlings. J Agric Sci Mansoura Univ 32:3651-3666

Elo S, Maunuksela L, Salkinoja-Salonen M, Smolander A, Haahtela K (2000) Humus bacteria of Norway spruce stands: plant growth promoting properties and birch, red fescue and alder colonizing capacity. FEMS Microbiol Ecol 31:143-152

Ennab HA (2016) Effect of humic acid on growth and productivity of Egyptian lime trees (citrus aurantifolia swingle) under salt stress. J Agric Res Kafr ElSheikh Univ 42(4):494-505

FAO (2018) Food and Agriculture Organization of the United Nation (FAO), FAOSTAT. Available at: http://www.fao.org/faostat/en/\#data/QC

Ferrara G, Brunetti G (2008) Influence of foliar applications of humic acids on yield and fruit quality of table grape cv. Italia J Int Sci Vigne Vin 42(2):79-87

Glick BR (1995) The enhancement of plant growth by free-living bacteria. Can J Microbiol 41:109-117

Goldstein AH, Liu ST (1987) Molecular cloning and regulation of a mineral phosphate solubilizing gene from Erwinia herbicola. Biotech. 5:72-74

Haggag Laila F, Shahin MFM, Maha A, Mahdy HA, El-Hady Eman S (2013) Effect of spraying humic acid during fruit set stage on fruit quality and quantity of Picual olive trees grown under Sinai condition. J Appl Sci Res 9(3):1484-1489

Haggag Laila F, Shahin MFM, Mahdy HA, Atteya Amira KG, Hassan HSA (2015b) Beneficial effect of NPK, pigeon manure tea and microbial fertilizers as soil 
application on growth of "Toffahi" and "Picual" olive seedlings. J Agric Tech 11(7):1565-1582

Haggag Laila F, Shahin MFM, Mustafa NS, Mahdy HA, Hassan HSA (2015a) Studies on the effect of vinasse, amino acids and humic acid substances as soil applications on fruit quality and quantity of Manzanillo olive trees. Middle East J. Appl Sci 5(4):984-991

Hidayatullah AK, Mouladad M, Ahmed N, Shah SA (2018) Effect of humic acid on fruit yield attributes, yield and leaf nutrient accumulation of apple trees under calcareous soil. Indian J Sci Tech 11(15):1-8

IOOC (2019 a) International Olive Oil Council. Available at: https://www. internationaloliveoil.org/wp-content/uploads/2020/04/HO-W901-29-11-2019-P.pdf

IOOC (2019 b). International Olive Oil Council. Available at: https://www. internationaloliveoil.org/wp-content/uploads/2020/04/OT-W901-29-11-2019P-1.pdf

Ismail AF, Hussien SM, El-Shall SA, Fathi MA (2007) Effect of irrigation and humic acid on Le-Conte pear. J Agric Sci Mansoura Univ 32:7589-7603.5

Jahromi AA, Khankahdani HH (2016) Effect of humic acid on some vegetative traits and ion concentrations of Mexican lime (Citrus aurantifolia Swingle) seedlings under salt stress. Inter J Hort Sci Tech 3(2):255-264

Khattab Magda M, Shaban AE, El-Shrief AH, Mohamed AS (2012) Effect of humic acid and amino acids on pomegranate trees under deficit irrigation. I: growth, flowering and fruiting. J Hort Sci Ornam Plants 4:253-259

Khattab Magda M, Shaban AE, El-Shrief AH, Mohamed AS (2014) Effect of humic acid and amino acids on pomegranate trees under deficit irrigation. II: fruit quality. Am Eurasian J Agric Environ Sci 14(9):941-948

Mahato P, Anoop B, Chauhan JS (2009) Effect of Azotobacter and nitrogen on seed germination and early seedling growth in tomato. Researcher 1(4):62-66

McCully ME (2001) Niches for bacterial endophytes in crop plants: a plant biologist's review. Aust. J. Plant Physiol 28:983-990

Mohammed SM, Fayed TA, Esmail AF, Abdou NA (2010) Growth, nutrient statues and yield of Le-Conte pear trees influenced by some organic and bio-fertilizer rates compared with chemical fertilizer. Bull Fac Agric Cairo Univ 61:17-32

Mosa WFAE-G, Paszt LS, Frąc M, Trzciński P, Przybył M, Treder W, Klamkowski K (2016) The influence of biofertilization on the growth, yield and fruit quality of cv. Topaz apple trees. Hort Sci 43(3):105-111

O' Donnell RW (1973) The auxin-like effects of humic preparations from leonardite. Soil Sci 116:106-112

Pregel F (1945) Quantitive organic micro analysis, 4th edn. J. A. Churchill Ltd., London, p 53

Rahil M, Jabi F (2015) Effects of supplementary irrigation plus humic acid application on olive production. Inter J Plant Soil Sci 4(3):273-280

Rengrudkij Ph, Partida GJ (2003) The effects of humic acid and phosphoric acid on grafted Hass avocado on Mexican seedling rootstocks. Proceedings $V$ World Avocado Congress, pp. 395-400,19-24th October 2003, Granada Málaga, Spain. Available at: http://citeseerx.ist.psu.edu/viewdoc/ download?doi=10.1.1.520.7442\&rep=rep $1 \&$ type $=$ pdf

Russo RO, Berlyn GP (1990) The use of organic biostimulants to help low input sustainable agriculture. J Sus Agric 1(2):9-42

Sándor F, Tolner L, Füleky G, Abdiani SA, Sanchez JE (2015) Humic substances applications impact quality and yield of commercially-produced pomegranate saplings in Nangarhar. Afghanistan J Agric and Enviro Sci 2(2):59-67

Senn TL, Kingma AR (2000) A review of humus and humic acids, pp. 1-5.

Shahin MFM, Genaidy EAE, Haggag Laila F (2015) Impact of amino acids, vinasse and humic acid as soil application on fruit quality and quantaty of 'Kalamata' olive trees. Inter J ChemTech Res 8(11):75-84

Tao Y, Ferrer J, Ljung K, Pojer F, Hong F, Long J, Li L, Moreno J, Bowman M, Ivans L, Cheng Y, Lim J, Zhao Y, Ballare C, Sandberg G, Noel J, Chory J (2008) Rapid synthesis of auxin via a new tryptophan-dependent pathway is required for shade avoidance in plants. Cell 133(164):178

Tattini M, Bertoni P, Landi A, Traversi ML (1990) Effect of humic acids on growth and nitrogen uptake of container-grown olive plant. Acta Horticulture 286: $125-128$

Tattini M, Bertoni P, Landi A, Traversi ML (1991) Effect of humic acids on growth and biomass partition of container grown olive plant. Acta Horticulture, 294: $75-80$.

Weller DG, Thomashow LS (1993) Use of rhizobacteria for biocontrol. Curr Opin Biotechnol 4:306-311

\section{Publisher's Note}

Springer Nature remains neutral with regard to jurisdictional claims in published maps and institutional affiliations.

\section{Submit your manuscript to a SpringerOpen ${ }^{\circ}$ journal and benefit from:}

- Convenient online submission

- Rigorous peer review

- Open access: articles freely available online

- High visibility within the field

- Retaining the copyright to your article

Submit your next manuscript at $\boldsymbol{\nabla}$ springeropen.com 